\title{
Installation of ventilated facades without scaffolding in high-rise buildings
}

\author{
Lyubov Gnedina ${ }^{1, *}$ Arina Muchkina $^{1}$, Alexander Labutin ${ }^{2}$ \\ ${ }^{1}$ Moscow State University of Civil Engineering, Yaroslavskoye shosse 26, Moscow, 129337, Russia \\ ${ }^{2}$ LTD "Polystyrene concrete", Ivanovo, Russia.
}

\begin{abstract}
This article consider the use of polystyrene concrete blocks during assembling enclosing structure of ventilated facades in high-rise monolithic housing construction. Comparing with traditional technology devices hinged ventilated facade the main advantage of the proposed design is an exception of using scaffold, that leads to a cheapening of the enclosing structure. Proposed solutions are confirmed by patents of the Russian Federation.
\end{abstract}

\section{Introduction}

Scientific and industrial cooperation of the Department of Construction materials Ivanovo State Architectural and Construction Academy and Labutin \& Co. started in 1996. The results of this cooperation are: the creation of "LIKO" raw mix for the production of filler heat insulation [1], a number of publications in the press $[2,3,4,10]$, check recording of calculation programs in sector funds of algorithms and programs [5 and 6], successful implemented developments in construction (sinus filling of grouted masonry of a 5-storey residential building in Pedagogichesky Lane and the assembling of heat-insulating layer on the roof of the baby food plant in Ivanovo).

\section{Materials and Methods}

Prefabricated blocks, wall panels (Fig. 2), beams and lintels made from custom (poured) heat insulation (Fig. 2). They passed a comprehensive certification test in the research, design and technological institute of concrete and reinforced concrete - NIIZhB named after A.A.Gvozdev and the Central Research Institute of Building Constructions named after VA Kucherenko - CNIISK and are widely used as load-bearing structure and enclosing structures. Monolithic high-rise housing construction as enclosing structures, as well as in the construction of public. Material and products made of the mixture proved its viability and included in the Code of Rules 32-101-2004. Fig. 3-5

\footnotetext{
* Corresponding author: gnedinalyu@mgsu.ru
} 


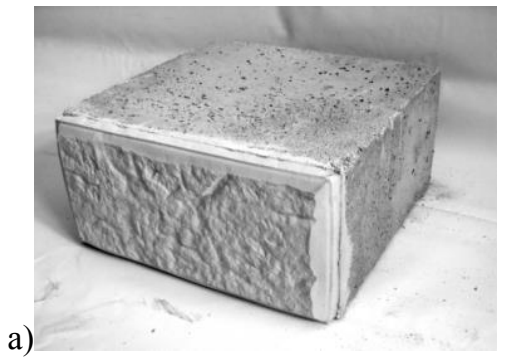

b)

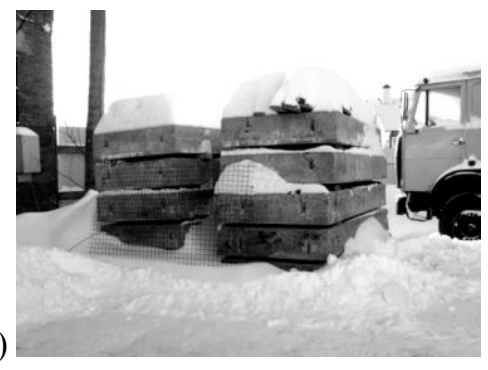

Fig. 1. a) The polystyrene concrete block with facing layer, b) The polystyrene concrete wall panels.

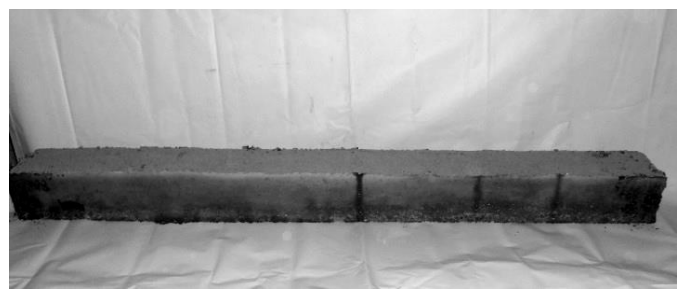

Fig. 2. The polystyrene concrete lintel.
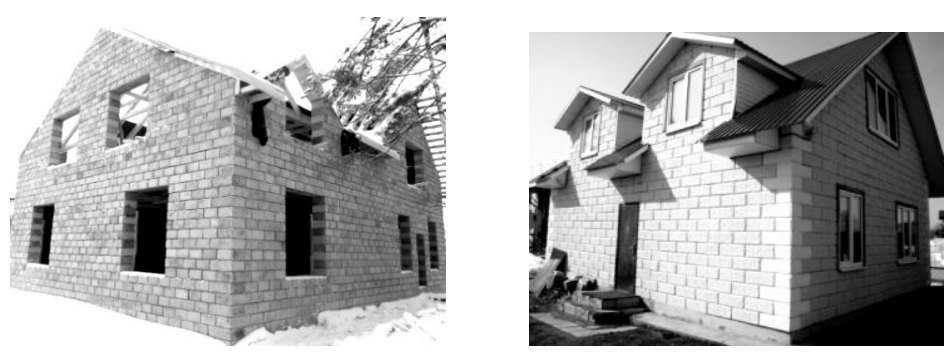

Fig. 3. Construction of the cottage with block
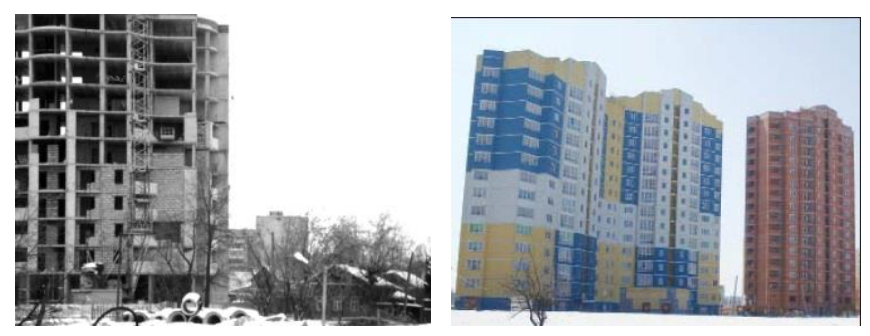

Fig. 4. Construction of a multistory building.
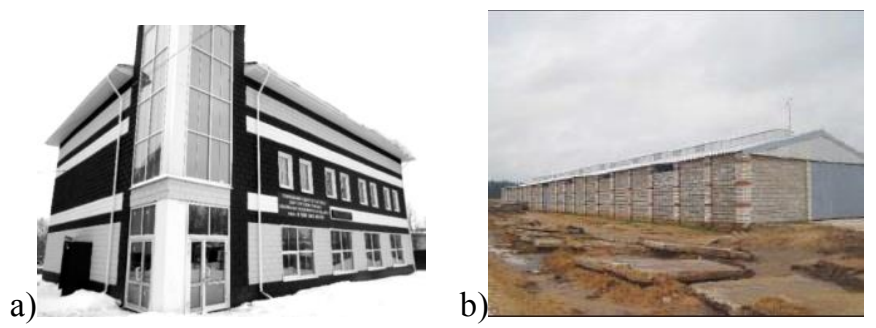

Fig. 5. Public building made of polystyrene concrete blocks and Industrial building for agricultural purposes. 
The advantages of polystyrene concrete over other slubby and poured heat insulations:

- The availability of raw materials;

- Ease of manufacture (does not require special high-tech equipment), minimum energy consumption for manufacture and relatively low cost;

- Adhesion of the filler material to the building materials and construction is comparable with the adhesion of construction masonry mortar;

- High thermal performance and saving them for a long time (for example, for the moderate climate Russia is not more than $200 \mathrm{~mm}$ in the thickness of the desired block of polystyrene grade 600 density);

- Massive foundations aren't required for low-rise buildings;

- Reducing the load on foundations in multi-storey and high-rise buildings; buildings;

- Heavy lifting equipment aren't required for the construction of prefabricated

- Ecological and biological stability is comparable to concrete and reinforced concrete;

- High maintainability;

- The possibility of forming on any templates;

- The possibility of ventilated facades without scaffolding

The disadvantages are low impact strength and the need for exterior and interior decoration of walls.

The last drawback is eliminated by the device inside polystyrene concrete blocks embedded details made of roll-formed sheet shape (Fig.10 and 11) [7 and 8]. Guides for the gypsum covering constructions (indoors) or fasteners for mounting tiles (outdoors) are attached to them. It is also possible to install ventilated facade that helps to remove condensation from the fence body.

\section{Results}

A construction of multi-storey buildings with ventilated facades is widespread in Russian cities at the present time. Conventional (classical) scheme of the ventilated facades installation on frame buildings is:

1. A filling of openings (with brick, gas silicate, foam concrete blocks, etc.);

2. An assembling of scaffolds;

3. An additional insulation with slabs of increased rigidity;

4. An installation of sufficiently strong metal frame;

5. Cladding with porcelain tile or composite panels;

This technology of ventilated facade installation is quite expensive and time consuming.

An undoubted advantage over the classical scheme has the $400 \mathrm{~mm}$ wall construction made of D-300-400kg / $\mathrm{m} 3$ polystyrene blocks with an installation of ventilated facade without scaffolding and additional heat insulation [9].

The erection of this enclosing structure is carried out after the erection of load-bearing structures of walls, columns and monolithic inter-floor reinforced concrete floor (Fig. 9 and 10). 


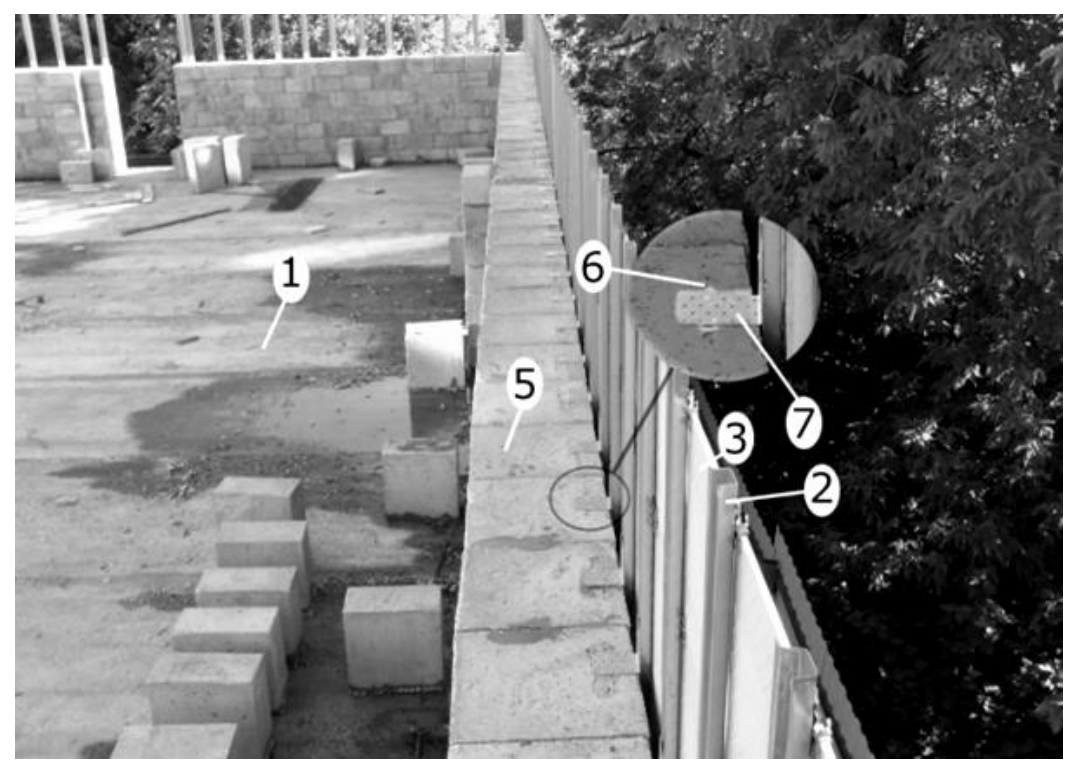

Fig. 6. The construction of the exterior walls using technology [9].

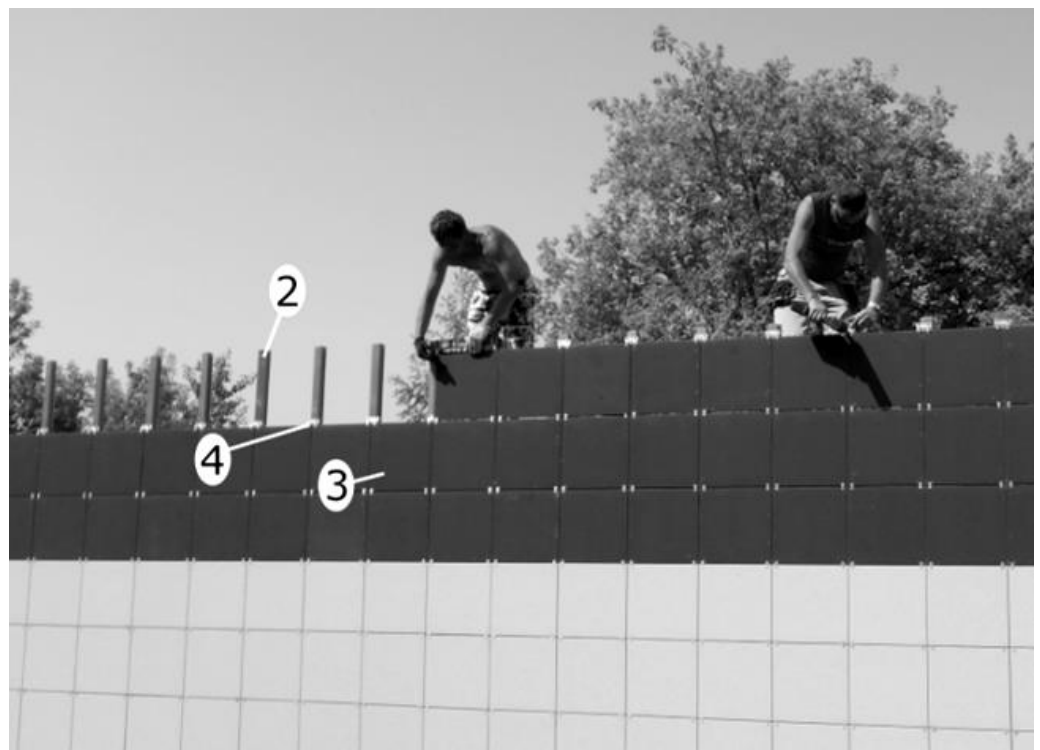

Fig. 7. The construction of the exterior walls using technology [9].

On the solid-cast overlap (1) (Fig.6 and 7) aligning profiles (2) are installed with metal brackets (6) in steps equal to the width of ceramic granite (3) or other finishing material. Thereafter, the cleats (4) are fixed on leveling profiles (2) and the porcelain tile (3) is installed from the ceiling to other ceiling. After cladding process polystyrene concrete blocks (5) with hardened metal padding (7) are fitted inside. Using the metal bracket (6), the unit is attached to the leveling profile (2).

So the construction of the enclosing wall is carried out without scaffolding directly from the overlap.

A heat insulation of such wall is not necessary, since the thickness of the polystyrene blocks is $400 \mathrm{~mm}$ and provides the required regulatory heat-shielding properties. 
Taking into account the foregoing, the erection of a walling structure with a ventilated façade from interfloor floors has the following advantages:

1. There are no costs for the installation of scaffolding;

2. There are no costs for insulation, hydro and wind-proof membrane;

3. The reduction of metal construction costs;

4. The reliability of construction by direct attachment to the porcelain stoneware wall with a ventilated gap of $30-40 \mathrm{~mm}$ (in the classical device ventilated facade porcelain stoneware is at a distance of $200-250 \mathrm{~mm}$ from the wall);

5. The reduction of the time of construction and installation works and ensuring the continuity of the process sequence of the construction of the enclosing structure (simultaneously conducted facing and filling of openings);

6. The total reduction in the cost of construction and installation works in 2 times.

Cost of $1 \mathrm{~m}^{2}$ of the construction (construction and installation work + materials + transport) is 5500-6000 rubles. The above technology was developed by the Director of

OOO Polystyrene Concrete (Labutin and Co) by Alexander N. Labutin and patented [9]. (phone for communication: +7 90387806 40). This technology has already been worked out in practice. Currently, the company carries out in the city of Ivanovo construction of multi-storey buildings with a ventilated facades without scaffolding and additional insulation. All works are carried out with interfloor overlappings.

\section{Conclusions}

Summarizing the above we can conclude that it became possible to abandon the multilayered enclosing structures with the internal location of the heat-insulating layer, and to return to proven and well-established design solutions of almost single-layer walls made of polystyrene concrete on a new qualitative level. This method will significantly reduce onetime and operating costs. In terms of heat loss such enclosing structure will have only one "narrow" place - contiguity place of window and door blocks to the body of the masonry or panel, so in this direction further scientific and engineering developments should be implemented.

\section{References}

1. S.V. Fedosov, A.M. Ibragimov, L.Yu. Gnedina, A.N. Labutin, Syr'evaya smes' dlya izgotovleniya zalivnogo uteplitelya (1998)

2. S.V. Fedosov, L.Yu. Gnedina, Zalivnoy uteplitel' na osnove penopolistirola (1999)

3. L.Yu. Gnedina, Optimal'noe mestopolozhenie uteplitelya v mnogosloynykh ograzhdayushchikh konstruktsiyakh (2000)

4. L.Yu. Gnedina, Zalivnoy uteplitel" «LIKO» v trekhsloynykh ograzhdayushchikh paneyakh (2006)

5. S.V. Fedosov, A.M. Ibragimov, L.N. Aksakovskaya, Raschet temperaturnykh poley raspredeleniya potentsiala perenosa massy $v$ trekhsloynoy stenovoy paneli (2003)

6. S.V. Fedosov, A.M. Ibragimov, L.Yu. Gnedina, S.A. Ignat'ev, Raschet tolshchiny teploizolyatsionnogo (srednego) sloya trekhsloynykh stenovykh paneley (stena 2) (2005)

7. Pat. № 74142 RF. $2007138288 / 2215.10 .2007$ (2008)

8. Pat. № 143759 RF. zayavle-no $2014109155 / 03$ 11.03.2014 (2014)

9. Pat. № 164519 RF. $2016109385 / 03$ 15.03.2016 (2016)

10. L.Yu. Gnedina, A.M. Ibragimov, A.A. Titunin, A.N. Labutin, Building materials, 10 21-23 (2016) 